\title{
Posmononocoor
}

2014, vol. 71, 3-13

http://dx.doi.org/10.12657/denbio.071.001

\author{
Katarzyna Sękiewicz, Maciej Sękiewicz, Angel Romo, \\ Yakiv Didukh, Mohamed Fennane, Adam Boratyński
}

\section{Chorological and conservation status of the endemic cypress, Cupressus atlantica Gaussen, in the High Atlas (Morocco)}

Received: 27 December 2012; Accepted 08 May 2013

\begin{abstract}
We present a study of the distribution, ecology and conservation status of Cupressus atlantica, an endemic tree of the High Atlas (Morocco). The main populations of this species grow in a reduced area along the N'Fiss valley in the Central High Atlas and are gradually receding. Particular populations are increasingly fragmented and the total area covered by the cypress woodland has decreased to less than a third of the surface occupied in the 1930s. Overgrazing reduces the woodlands' regenerative capacity, and the exploitation of the wood, linked to traditional uses by the rural society of the N'Fiss valley, directly reduces the number of trees. Great efforts being made to protect the species by the Haut Commissariat aux Eaux et Forêts are having some effect in recent years.
\end{abstract}

Additional key words: Cupressaceae, degraded forest ecosystems, ecology, Moroccan Cypress, Moroccan flora, North Africa, plant conservation, plant geography.

\begin{abstract}
Addresses: A. Boratyński, K. Sękiewicz, M. Sękiewicz, Polish Academy of Sciences, Institute of Dendrology, 5 Parkowa str., 62-035 Kórnik, Poland, e-mail:borata@man.poznan.pl A. Romo, Consejo Superior de Investigaciones Científicas, Institute of Botany (IBB-CSIC-ICUB), Passeig del Migdia s/n, 08038 Barcelona, Spain, e-mail: a.romo@ibb.csic.es

Ya. Didukh, M.G. Kholodny Institute of Botany of National Academy of Sciences of Ukraine. Kyiv. Ukraine M. Fennane, Institut Scientifique. Dépt. de Botanique et Ecologie Végétale, Rue Ibn Battouta, B.P. 703, Agdal 10106, Rabat, Maroc (Morocco)
\end{abstract}

\section{Introduction}

Cupressus atlantica Gaussen, commonly known as the Moroccan Cypress, Cyprès de l'Atlas or Azel, is a tree up to about 18-20 m high and to 1.6, sometimes even to $2 \mathrm{~m} \mathrm{DBH}$ (Farjon 2005). The scientific literature has recorded the presence of $C$. atlantica in the Central High Atlas since Jahandiez and Maire (1931) and Emberger (1938), both after data by Brives (1909), but years passed before it was described by Gaussen (1950). Emberger (1938) and Emberger and Maire (1941) had already indicated the exceptional, relictic nature of $C$. atlantica, a testimony of past ages under different climatic conditions. Following Gaussen's (1950) description, the bibliography of this taxon has been scant. It is only recently that it 
has become an object of interest, with contributions from Bellefontaine (1979), Silba (1998), Alifriqui et al. (1996), El Alaoui et al. (2001), Bechir et al. (2001) and lately it reappears in synthetic works by Farjon (2005, 2010), Debreczy and Racz (2011) and Quézel and Médail (2003).

From the nomenclatural point of view, the position of C. atlantica is not free of controversy (Debreczy and Racz 2011). It was combined by Silba (1981) at the varietal level C. sempervirens L. var. atlantica (Gaussen) Silba, Phytologia 49(4), p. 398 (1981). Then the rank was changed by the same author (Silba 1998) to a variety of $C$. dupreziana A. Camus, in "a home made 'journal' of unknown distribution" (but distributed to NYBG and RBG Kew) as photocopied texts from his earlier writings pasted together, see above: $C$. dupreziana var. atlantica (Gaussen) Silba, comb. nova, 29", according to Farjon (2005). Later, this same author proposed the combination at subspecific level. On the whole, the specific rank seems to be the most adequate, though this should not be to the detriment of the conclusions of future studies, as proposed recently (Rushforth et al. 2003; Earle 2008).

Cupressus atlantica Gaussen in Le Monde des Plantes, 14: 55 (1950).

Syn.: Cupressus sempervirens L. var. atlantica (Gaussen) Silba in Phytologia 49: 398 (1981); Cupressus dupreziana A.Camus var. atlantica (Gaussen) Silba in J. Int. Conifer Preserv. Soc., 5(2): 29 (1998); Cupressus dupreziana A.Camus subsp. atlantica (Gaussen) Silba in J. Int. Conifer Preserv. Soc. 12(2): 64.2005 [Jul 2005]

Cupressus atlantica is a species endemic to the Moroccan High Atlas, where its largest populations are known from the N'Fiss valley, growing at altitudes between 1200 and $1800 \mathrm{~m}$ (Charco 2001), extended recently to the altitudinal range $1000-2000 \mathrm{~m}$ (Oldfield et al. 1998), or even 900 to 2220 m (El Wahidi 2004; Farjon 2005). The area, covered with cypress plant communities or juniper woodlands with admixture of C. atlantica was estimated at about 5500 ha by Gaussen (1950), but lately as only 1480 ha by Ech-Chamikh (1983), 1460 ha by Achhal (1986) and 8898 ha by El Wahidi (2004). The rest of the nearby stands and open woodlands of C. atlantica, frequently with Juniperus phoenicea L., at the lower part of the altitudinal range, also with Tetraclinis articulata (Vahl) Mast., and at the upper, Quercus ilex L. (Charco 2001), were reported mostly on the slopes of the N'Fiss Valley and some lateral valleys. C. atlantica is able to survive in the continental climatic conditions, with high oscillations of temperature and a low precipitation (Alifriqui et al. 1995; Quézel and Médail 2003). Soils covered with $C$. atlantica communities are generally poorly developed, rocky and strongly eroded.
Cupressus atlantica plays an important social role in Morocco. The wood of the species is used by the local population for construction and for home uses, also as a fuel for cooking and heating, and, during the last decades, for the production of souvenirs for tourists. The young twigs with leaves are fed to sheep and goats. The permanent exploitation of C. atlantica wood and the overgrazing of the terrains are recognized causes for the decrease in the number of individuals and lack of successful regeneration (F.A.O. 1976; Griffith 1998; El Wahidi 2004; Farjon 2005; Ouahmane et al. 2006).

Considerable attempts are being made by the Moroccan Forest Service (Haut Commissariat aux Eaux et Forêts) to replant $C$. atlantica in its area of distribution in the Oued N'Fiss Valley, but the rate of success is low (Oldfield et al. 1998; Ouahmane et al. 2006). It has been found lately that the use of 'plant nurses' such as Thymus saturejoides Cosson or Lavandula spp. can be of great value to restore a vegetation cover with participation of the Atlantic cypress (Ouahmane et al. 2006; Duponnois et al. 2011). These plant species operate not only as a mechanical protection of young seedlings, but also as a source of fungi which form arbuscular mycorrhiza, characteristic for C. atlantica (Ouahmane et al. 2007). In any case, knowledge of this tree is fragmentary and incomplete. Among other aspects, the detailed distribution, ecology, population dynamics and state of conservation are still insufficiently known.

The aims of this study were to: 1) estimate the area covered with the groves and woodlands of or containing specimens of $C$. atlantica in their main area of distribution in the N'Fiss valley, 2) determine the environmental conditions favouring its occurrence, 3) summarize the phytosociological character of communities which it forms or enters, as a background to conservation activities needed to preserve this endemic and endangered species with the IUCN category EN (A1bc, B1+2b) (IUCN 2006).

\section{Methods}

\section{Study area}

The study area covers the main part of the natural geographical range of $C$. atlantica in the N'Fiss valley, in the Moroccan High Atlas (Fig. 1). The Oued N'Fiss, due to its general orientation from NE to SW and huge dimensions, presents the characteristics of inland valleys situated within a mountainous region. It exhibits a specific climate, where the low rainfall is combined with a continental regime and with a high daily temperature oscillation. The N'Fiss valley remains clearly screened from any type of Atlantic climate influence, being surrounded by high mountains, with peaks and mountain passes reaching al- 


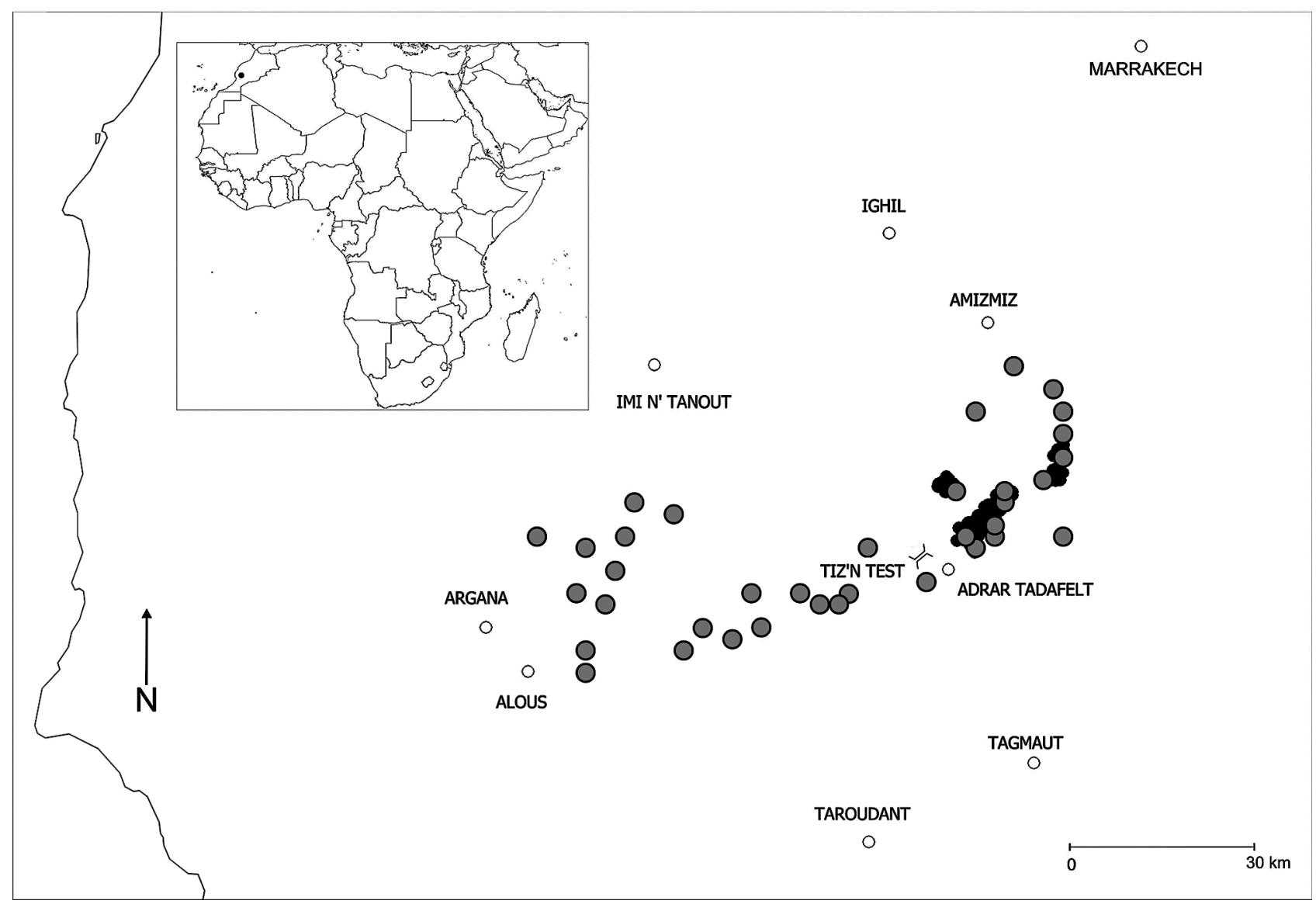

Fig. 1. Distribution of Cupressus atlantica in the High Atlas after Alifriqui (1996) and El Wahidi (2004): grey circles and own data: black circles (MapInfo v. 9.5)

titudes over 3600 and $2400 \mathrm{~m}$, respectively. Even to the $\mathrm{S}$, the peaks reach beyond $2700 \mathrm{~m}$. The only two lower reaches are the Tizi-n-Test pass $(2092 \mathrm{~m})$ to the South-West and the river N'Fiss gorge, which is downstream, in the lower part of the valley $(980 \mathrm{~m})$ to the North (Alifriqui et al. 1995).
The exceptional dry and continental nature of the valley is attested to by the presence of species like Warionia saharae Cosson, Kleinia anteuphorbium (L.) Haw. and Cymbopogon schoenanthus (L.) Spreng. The summers in the valley are very hot and the winters cold, in both cases with strong oscillations of daily and even extreme average monthly temperatures (Ta-

Table 1. Average month temperature with monthly average minimum and maximum at Tizi-n Test (after El Wahidi 2004)

\begin{tabular}{lrrrrrrrrrrrr}
\hline \multicolumn{1}{c}{$\begin{array}{c}\text { Temperature } \\
{\left[{ }^{\circ} \mathrm{C}\right]}\end{array}$} & Jan. & Feb. & Mar. & Apr. & May & June & July & Aug. & Sept. & Oct. & Nov. & Dec. \\
\hline
\end{tabular}

Table 2. Average precipitation within the N'Fiss valley (after El Wahidi 2004)

\begin{tabular}{|c|c|c|c|c|c|c|c|c|c|c|c|c|c|c|c|}
\hline \multirow{2}{*}{ Climate station } & \multicolumn{6}{|l|}{$\begin{array}{l}\text { Alti- } \\
\text { tude }\end{array}$} & \multicolumn{7}{|c|}{ Month } & \multirow{2}{*}{ Total } & \multirow{2}{*}{ Period } \\
\hline & {$[\mathrm{m}]$} & Jan. & Feb. & Mar. & Apr. & May & June & July & Aug. & Sept. & Oct. & Nov. & Dec. & & \\
\hline Ijoukak & 1185 & 51.7 & 41.4 & 38.1 & 30.0 & 12.2 & 4.4 & 3.4 & 7.6 & 29.7 & 31.8 & 57.3 & 38.6 & 346.2 & 1942-1972 \\
\hline Tlat n-Ya'qoub & 1233 & 35.6 & 22.9 & 28.1 & 16.8 & 9.1 & 4.8 & 1.1 & 5.9 & 14.1 & 36.8 & 40.5 & 24.8 & 240.5 & 1930-1971 \\
\hline Idni & 1700 & 105.9 & 88.7 & 39.5 & 29.0 & 9.4 & 3.1 & 4.7 & 6.6 & 14.6 & 95.0 & 154.3 & 81.8 & 634.6 & 1953-1972 \\
\hline Tizi-n Test & 2080 & 54.0 & 58.0 & 74.0 & 80.0 & 57.0 & 14.0 & 4.0 & 4.0 & 25.0 & 48.0 & 58.0 & 68.0 & 544.0 & 1933-1963 \\
\hline Aghbar & 2700 & 105.8 & 85.6 & 65.6 & 30.1 & 11.3 & 5.5 & 2.1 & 11.7 & 24.7 & 91.1 & 137.3 & 130.5 & 701.5 & 1938-1972 \\
\hline
\end{tabular}


ble 1). In the lower parts of the N'Fiss valley, the annual precipitation is below $400 \mathrm{~mm}$ and in higher parts about $500-600 \mathrm{~mm}$ (Table 2). In this area, the rainiest season is winter, followed by autumn, spring and summer (WASpSu), after Alifriqui et al (1995) and El Wahidi (2004). The N'Fiss valley area is situated on the border of two different pluviometric regimes, because it is not far from the zone where the rainiest season is spring, followed by winter, autumn and summer (SpWASu) (Alifriqui et al. 1995).

\section{Field measurements}

The data on the distribution of C. atlantica was gathered from literature and herbaria. Field studies were then conducted during the first days of September 2005 and July 2008. The distribution of populations, groups of trees and single individuals has been mapped in the N'Fiss valley using topographic maps 1:100,000 of Amezmiz (1974. Ministère de l'Agriculture et de la Reforme Agraire, Division de la Carte, Rabat) and Tizi'n Test (1974. loc. cit). The toponyms were also adopted from these maps. The area of particular tree conglomerations and parts of the stands were estimated directly in the field and verified on the map. The area of each unit was approximated to about $0.04-0.05$ ha. The single trees and groups of trees covering terrain smaller than about $20 \times 20 \mathrm{~m}$ were not included into the estimated area. The data obtained were compared to those known from the literature, and the tendency of the population to increase/decrease its area was estimated.

The type of rock, main relief form, exposure and inclination have been determined for localities of the species in the field (Boratyński 1985). We have distinguished three main categories of the ground where C. atlantica grows (1) limestone rock fissures and gravels, (2) schist rocks and gravels and (3) sandstone fissures and gravels, which are consistent with the High Atlas Geology (Hollard et al. 1985).

The main relief forms included slope, frequently with terraces (ZB), concave forms, such as slope troughs, stream valleys, gorges, etc. (WKL), and convex forms, such as slope protuberances, ridges, great rocks, etc. (WYP). The exposure of localities was determined according to the 4 main and 4 intermediate geographic directions, N, NE, E, etc. Inclination included categories (1) to $10^{\circ}$, (2) $11-20^{\circ}$, (3) $21-30^{\circ}$, (4) $31-45^{\circ}$ and (5) more than $45^{\circ}$. The exposure and inclination was measured in the field using compass (Sylva) and clinometers (Suunto), respectively.

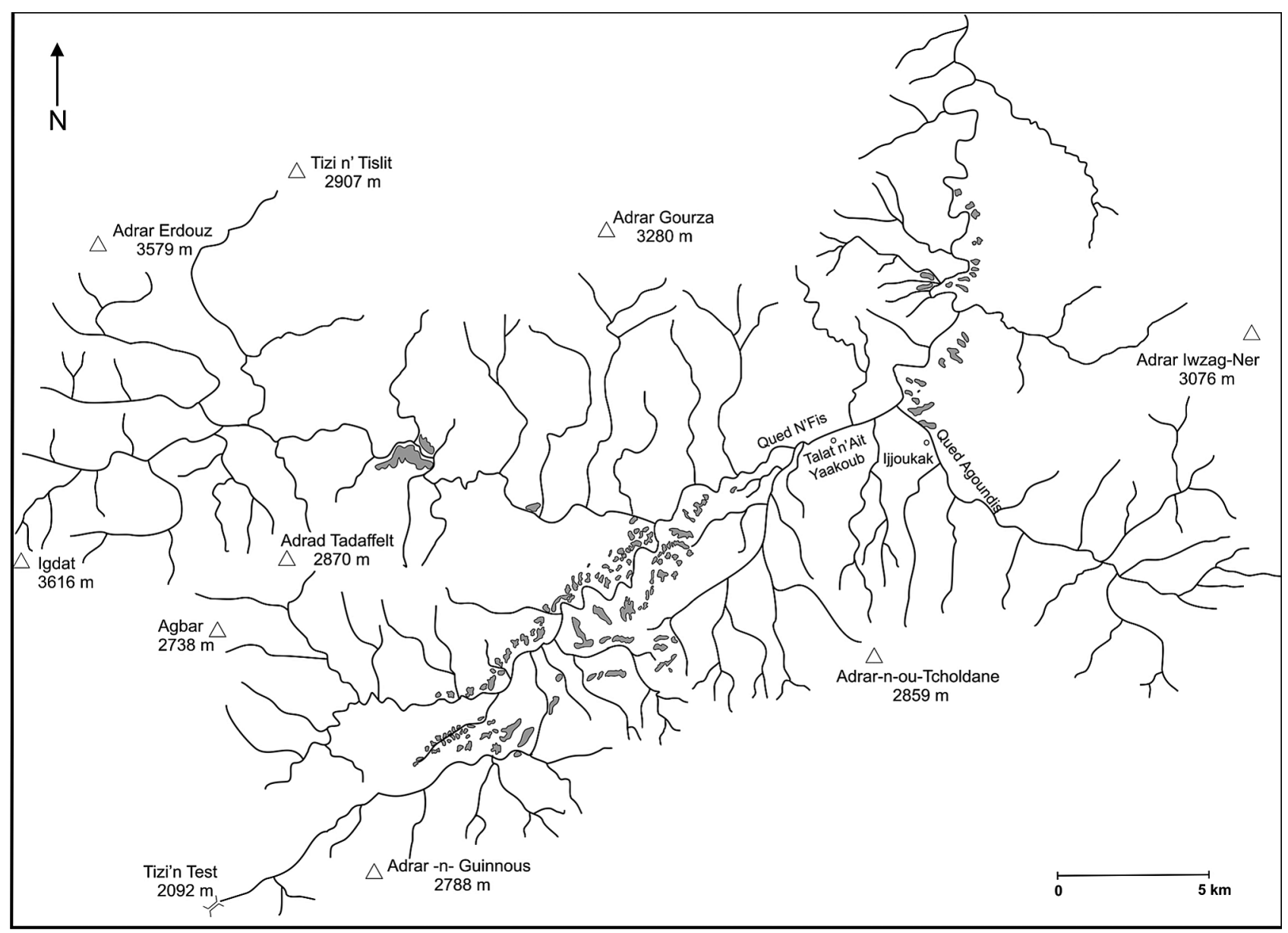

Fig. 2. Localities of Cupressus atlantica in the Oued N'Fiss valley based on field observations 
The most representative localities were documented phytosociologically according to the Braun-Blanquet (1979) method. We have made inventories in order to recognize the vegetation communities, to analyze the species accompanying the cypress and to document presence/absence of seedlings and saplings of $C$. atlantica. We compared our phytosociological reléves with data concerning similar plant communities, accessible in the literature, to verify the possible specific plant composition of this $\mathrm{Cu}$ pressus woodland. The nomenclature of taxa follows Fennane et al (1999; 2007).

\section{Results}

\section{Area of distribution}

Although the main centre of $C$. atlantica occurrence covers slopes of the valley of the Oued N'Fiss, there are several small populations of the species dispersed in other valleys, harbouring as a rule not as many individuals (Fig. 1). The Atlantic cypress has been reported also from isolated localities, such as to the SW of Tizi'n Test close to Adebni village, situated on northern slopes of a lateral valley at $1450 \mathrm{~m}$. Several other localities have been found on the southern and western slopes of Adrar Aoulime, towards Imoulas and the Assif n'Aït Tament, Assif Togouga, Assif Medlawa and Assif n'Aït Cha'ib (western localities of Fig. 1). Another one is situated on the northern slopes of Adrar Tadafelt, close to the village of the same name (Fig. 2). Other smaller and reduced populations are found at Southern Amizmiz, Imi n'Tanout, North-East and East Argana (Appendix 1).

We detected three nuclei of $C$. atlantica in the Oued N'Fiss. The first exists between Imidel and Ijoukak, the second, better nourished, between Talat-n-Ya'qoub and Tizi-n-Test and the third between Iguer and Taourirt in the lateral valley of Taslit, which descends from Tizi-n Taslit (Fig. 1). The first nucleus is calculated to occupy about 423 hectares, the second about 959 and the third around 298. The species-loose groves cover about $70 \%$ of that area, so its woodland area was about 2180 hectares during field studies in 2005 and 2008, with an average tree layer coverage of about $30 \%$ (Appendix 2).

We have observed individuals of $C$. atlantica in the N'Fiss Valley at altitudes between 1060 and $1690 \mathrm{~m}$, with the best conserved woodlands between Mzouzit and Idni (Fig. 2), at altitudes of 1400-1700 m. The patches of the forest have been observed at that elevation, while below and above that belt the species forms, as a rule, open groves across rather restricted areas, or grows in the form of dispersed, single trees. Besides this, a small group of $C$. atlantica trees has also been observed on the south facing slopes of Tizi'n Test, at an altitude of $1700 \mathrm{~m}$. Judging by the distribution and demographic structure, in this case we are most likely talking about planted trees.

\section{Occurrence conditions}

\section{Lithology}

The occurrence of $C$. atlantica appears to be uninfluenced by substrate type, and the species can be found equally on slightly acid soils made up of sandstones and schist, as on carbonated soils, originating from dolomites. It always occurs on shallow, undeveloped, stony and strongly eroded soils, where the stones measure more than $30 \mathrm{~cm}$ in diameter and cover more than $50 \%$ of the area. In many cases, it is found on slopes with rock slabs of over one metre in diameter.

\section{Relief forms}

In the localities studied, slopes dominate, concave sites are rare, and convex sites are absent. The species has been observed mostly on the lower and middle slopes, but completely absent on their upper parts. In the middle parts of high slopes, it occurs above all at the foot of rocks and small rocky terraces or in concave relief forms, such as the dry beds of small streams, slope hollows, small gullies, etc. C. atlantica is more frequent on the lower flanks of the valleys but does not enter riparian communities. It constitutes a transition between the hygrophilous riverine vegetation and the communities dominated by J. phoenicea, which colonize the drier environments with shallower soils typical of the upper parts of the slopes.

Most of the localities of the cypress were observed on slopes inclined between 20 and $45^{\circ}$, although in exceptional cases also on more abrupt ones (Fig. 3A). The species stands on the most precipitous slopes occur in valleys moulded by fluvial activity and, consequently, strongly eroded.

\section{Aspect}

The patches of communities with $C$. atlantica are found above all on the slopes exposed to $\mathrm{N}$ and NW, and become scarcer on S and SW facing slopes (Appendix 1, 2, Fig 3B). The association of the species or communities with their co-dominance was documented from the N, NW and $\mathrm{W}$ aspects (Appendix 2 ), but localities were found quite frequently also on the slopes exposed to $\mathrm{S}$ and SE (Fig. 3B).

\section{Phytosociological characteristic}

\section{Floristic composition}

We documented 33 relevés of $C$. atlantica woodland in different parts of the N'Fiss and Taslit valleys (Appendix 2). All of them represent the plant community from the Ephedro nebrodensis-Juniperion 


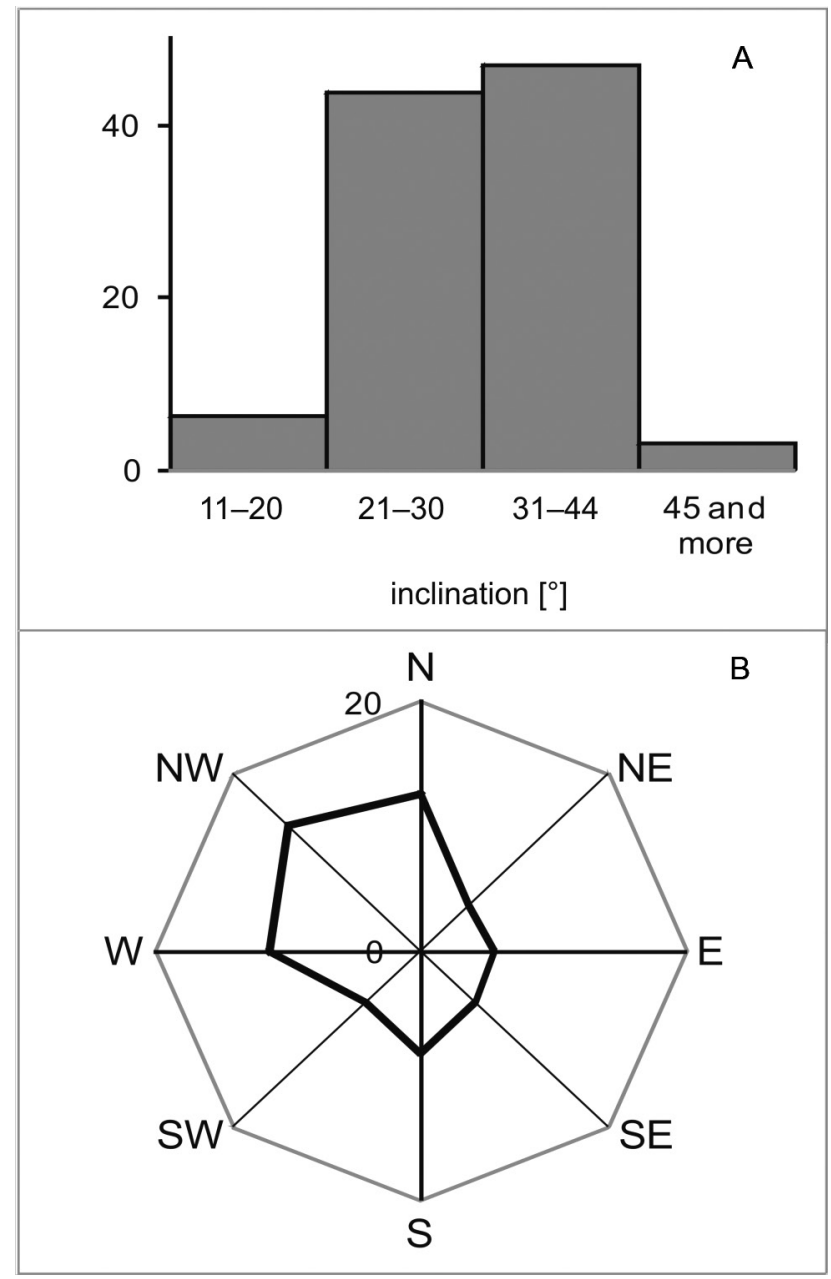

Fig. 3. Occurrence of Cupressus atlantica depending on: A - inclination of the slopes; B - exposure; based on the phytosociological data and authors' field observations

turbinatae Quézel \& Barbero (1981) 1986 alliance, but in respect to the floristic composition they pertain to none of the associations already described (Table 3). For that reason, we decided to describe them as a new plant association: Micromerio hochreuteneri-Cupressetum atlanticae; the relevé number 25 in Appendix 2 is chosen as type. It is close to the Junipero turbinatae-Cupressetum atlanticae Quézel \& Barbero 2007 in Asensi, Díaz-Garretas \& Quézel and should be included in the Ephedro nebrodensis-Juniperion turbinatae alliance, order Ephedro-Juniperetalia Quézel \& Barbero 1981 ex Quézel, Barbero, Benabid, Loisel \& Rivas-Mart. (1988) (Table 3).

The number of species in particular inventories of Micromerio hochreuteneri-Cupressetum atlanticae oscillated between 9 and 26 per $100 \mathrm{~m}^{2}$. The High Atlas endemics, apart from the cypress, are Polygala balansae Coss., Coronilla ramosissima Ball and Lavandula pedunculata (Mill.) Cav. subsp. atlantica (Braun-Blanq.) Romo. The plant species typical for the open areas include most frequently: Avenula bromoides (Gouan)
H.Scholz, Cymbopogon schoenanthus Spreng., Globularia alypum L., Lavandula dentata L. and Thymus saturejoides Coss. \& Balansa. Also, there are some ruderal plants that occur less frequently, such as Poa bulbosa L., Dittrichia viscosa (L.) Greuter and Piptatherum miliaceum E.Fourn. (Appendix 2).

\section{Canopy structure}

In the woodland communities with C. atlantica, the tree canopy rarely reaches a coverage of more than $40 \%$, and the tree height oscillates between 4 and $10 \mathrm{~m}$. We cannot speak of a dense forest formation but rather of trees, in this case C. atlantica, Juniperus phoenicea and J. oxycedrus L., below which a dense shrub canopy is developed, where the herbaceous plants play a minor role. The trees do not modify excessively the amount of light that penetrates to the ground below the canopy. In fact, we are referring to a plant community dominated by trees in which the term 'woodland' can only be applied in a wide sense.

One of the main goals of the phytosociological inventories was to detect the seedlings of $C$. atlantica in nature. Unfortunately, we found not one seedling during the whole field study period, not only in our phytosociological relevés.

\section{Discussion}

\section{Area of woodlands}

The localities of $C$. atlantica are dispersed within the northern macro-slope of the High Atlas. The species occurs in the valleys with populations separated from each other by distance and high mountain ridges. The most numerous and best known conglomeration covers the N'Fiss valley, where Atlantic cypress occurs between Imidel and Ijoukak and then between Talat-n'Ya'qoub and Tizi-n'Test. The lateral valley of Taslit, close to the N'Fiss valley, between Iguer and Taourirt, harbours quite large populations, which cover about 300 ha (Fig. 2). The species-open groves cover about $70 \%$ of these three regions and the total area of woodland with $C$. atlantica was estimated at about 2200 ha in the first decades of the 20th Century (Watier 1921; Jahandiez and Maire 1931; Emberger 1938; Gaussen 1950). The first great area of occurrence of $C$. atlantica, easily accessible from the road from Marrakesh to Tizi-n-Test, covers at present about $420-430$ ha and is not the most abundant population of the species, despite the view of Farjon (2005), although that may have been years ago. Several large trees have been found there with the circumference of $4-5 \mathrm{~m}$ at $1.3 \mathrm{~m}$ above ground level. The largest cypress trees are near the Ijoukak Forest Station. Some of them were drawn by Farjon (2005). Most of the trees show signs of cutting for wood and lopping for animals. 
Table 3. Associations of the Ephedro majoris-Juniperion phoeniceae Quézel et Barbero (1981) 1986 alliance: A: Coronillo ramosissimae-Juniperetum phoeniceae Quézel et Barbero (1981); B: Warionio saharae-Antirrhinetum ramosissimae Quézel et Barbero (1981); C: Retamo dasycarpae-Juniperetum phoeniceae Quézel et Barbero (1981); D: Junipero turbinati-Cupressetum atlanticae Quézel et Barbero 2007 in Asensi, Díaz-Garretas et Quézel and E: Micromerio hochreuteneri-Cupressetum atlanticae, ass. nova

\begin{tabular}{|c|c|c|c|c|c|}
\hline Species & $\mathrm{A}$ & $\mathrm{B}$ & $\mathrm{C}$ & $\mathrm{D}$ & $\mathrm{E}$ \\
\hline Cupressus atlantica & & & & $\mathrm{V}$ & $\mathrm{V}$ \\
\hline Ephedra nebrodensis & $\mathrm{V}$ & $\mathrm{V}$ & $\mathrm{V}$ & $\mathrm{V}$ & $\mathrm{V}$ \\
\hline Polygala balansae & II & & $\mathrm{V}$ & $\mathrm{V}$ & $\mathrm{V}$ \\
\hline Thymus saturejoides & & & I & IV & $\mathrm{V}$ \\
\hline Lavandula dentata & III & & & III & IV \\
\hline Phagnalon saxatile & I & & II & & III \\
\hline Ballota hirsuta & $\mathrm{I}$ & & & & II \\
\hline Globularia alypum & III & III & II & & II \\
\hline Lavandula pedunculata subsp. atlantica & I & & I & & II \\
\hline Asparagus albus & $\mathrm{V}$ & & & I & I \\
\hline Cistus creticus & & & & & I \\
\hline Ephedra fragilis & I & $\mathrm{V}$ & II & & I \\
\hline Cladanthus scariosa & & & $\mathrm{V}$ & & I \\
\hline Pistacia atlantica & IV & & III & & I \\
\hline Polycnemum fontanesii & I & & III & & I \\
\hline Quercus rotundifolia & & & II & I & I \\
\hline Rhus tripartita & IV & III & & & I \\
\hline Salvia taraxicifolia & II & & III & & I \\
\hline Stipa lagascae & & & III & & I \\
\hline Stipa nitens & I & & IV & & I \\
\hline Ziziphus lotus & I & & & I & I \\
\hline Acanthorrhinum ramosissimum & & $\mathrm{V}$ & & & \\
\hline \multicolumn{6}{|l|}{ Asparagus stipularis } \\
\hline Bupleurum dumosum & III & & & & \\
\hline Capparis spinosa & IV & & & & \\
\hline Ceratonia siliqua & I & & & & \\
\hline Chamaerops humilis & & & IV & & \\
\hline Coronilla ramosissima & $\mathrm{V}$ & & II & III & II \\
\hline Cytisus balansae & & & $\mathrm{I}$ & & \\
\hline Fraxinus dimorpha & & & I & & \\
\hline Hedysarum membranaceum & & III & & & \\
\hline Juniperus oxycedrus & & & IV & III & III \\
\hline Juniperus phoenicea & $\mathrm{V}$ & & $\mathrm{V}$ & $\mathrm{V}$ & $\mathrm{V}$ \\
\hline Lavandula multifida & I & & & & \\
\hline Olea europaea subsp. oleaster & I & & & & I \\
\hline Periploca angustifolia & & & & IV & \\
\hline Retama dasycarpa & & $\mathrm{V}$ & & & \\
\hline Micromeria hochreutineri & & & & & II \\
\hline Stipa tenacissima & & & IV & & \\
\hline Tetraclinis articulata & I & & & & \\
\hline Warionia saharae & II & $\mathrm{V}$ & & III & \\
\hline
\end{tabular}

The most extended area of the woodland communities with C. atlantica covers about 960 ha above Talat-n-Ya'qoub, through Mzouzit, Moulddikht and Idni, toward the pass of Tizi-n-Test, up to an altitude of about $1700 \mathrm{~m}$. The largest trees we have observed there were also more than 23-24 m high and about 4 $\mathrm{m}$ circumference. The high number of trees is probably a reason for the fact that the injuries are not so visible as in the lower part of the valley. Nevertheless, there are also small goods made from the cy- press wood, available for purchase in villages along the road.

The extensive area covered with woodland of $J$. phoenicea and Q. ilex in the Atlas suggests the much wider occurrence of $C$. atlantica in the past (Charco 1999). The existing remnants of forest of C. atlantica are rare and can be met with in inaccessible, high parts of the valleys or in the vicinity of villages. Predominantly, these forests have a marked open structure and can be thought of as cypress or cypress-ju- 
niper woodlands or woodland steppe. The low layer of that community contains several woody and perennial species of open areas, including some endemic plant species of the High Atlas (Charco 1999).

\section{Altitudinal limits}

The numerous populations in the N'Fiss valley of the High Central Atlas are located between 1300 and $1585 \mathrm{~m}$, but we have observed single and/or groups of individuals between 1060 and $1690 \mathrm{~m}$. Open associations and small copses can be found approaching both the upper and the lower altitudinal limits. If we contrast these data with those of the bibliography, we can see that the limits indicated by Emberger (1938) between 1100 and $1800 \mathrm{~m}$, by Charco (2001) between 1200 and $1800 \mathrm{~m}$, or by Benabid and Fennane (1994) between 1000 and $1800 \mathrm{~m}$, are in closer conformity with our findings than the data presented by Benabid (2000) between 900 and 1400 m, 1100 and $2200 \mathrm{~m}$ by Alifriqui (1995) or by Farjon (2005) between 900 and $2220 \mathrm{~m}$.

\section{Occurrence conditions}

We did not find a direct influence of the substrate on the occurrence of C. atlantica, although we have never found it on the basalts, as reported by Earle (2008). The species has been observed on the slightly acid, undeveloped soils overlying sandstones, more basic soils on schists, and the carbonated soils on the dolomites (Hollard et al. 1985). The soils are as a rule poorly developed or undeveloped, very stony and covered with stones and rocks (Appendix 2 ). The same types of substrate were reported earlier for communities of $C$. atlantica (Quézel and Barbero 1981; Ech-Chamikh 1983; Achhal 1986; Quézel et al. 1994; Alifriqui 1995; El Wahidi 2004).

The close connection of the remnants of the $C$. atlantica groves with the strongly inclined slopes, observed in the field, may reflect the smaller accessibility of such a site and its uselessness for human agricultural activity. It concerns mostly the vicinities of villages and settlements, where some less steep slopes have been converted into small patches of vegetable plots, especially in the basal parts of the hills. The old trees, existing among settlements or not far from them, have been preserved for their shade. Some of them are of impressive dimensions, as near the Ijoukak Forest House (Maison Forestière, Ijoukak).

The northern or close to northern exposures (Fig. 3B) and slightly concave forms of the terrain at most of the localities can indicate the higher degree of survival of C. atlantica in the N'Fiss valley on the sites retaining humidity for a longer time span, when compared to the drier conditions present on the southern slopes and raised relief forms. The predominantly winter precipitation and very restricted rain during spring and summer over the studied area (Alifriqui 1995; Alifriqui et al. 1995) are probably a limitation for the cypress, which is replaced on the drier sites by junipers.

\section{Phytosociology}

The specific species composition of woodland with C. atlantica (Table 3, Appendix 2) led Asensi et al. (2007) to propose a new syntaxon Junipereto turbinatae-Cupressetum atlanticae Quézel et Barbero in Asensi et al. 2007. The first eight inventories published by Quézel and Barbero (1981) as Coronillo ramosissimae-Juniperetum phoeniceae subass. cupressetosum atlanticae Quézel et Barbero 1981, nom. inval., ought also to be referred to this syntaxon. The Junipereto turbinatae-Cupressetum atlanticae belongs, together with Coronillo ramosissimae-Juniperetum phoeniceae Quézel et Barbero (1981), Warionio saharae-Antirrhinetum ramosissimae Quézel et Barbero (1981), Retamo dasycarpae-Juniperetum phoeniceae Quézel et Barbero (1981) and Micromerio hochreuteneri-Cupressetum atlanticae to the alliance Ephedro nebrodensis-Juniperion Quézel et Barbero (1981) 1986, order Ephedro-Juniperetalia Quézel et Barbero 1981 ex Quézel, Barbero, Benabid, Loisel et Rivas-Mart. (1988).

The Junipero turbinatae-Cupressetum atlanticae is characterized by the high frequency of $C$. atlantica, Polygala balansae, Asparagus albus L., Thymus saturejoides and Ephedra nebrodensis Guss. The high number of Atlas endemic plants which are observed in this association is Noteworthy. Apart from the cypress, Polygala balansae, and Coronilla ramosissima are frequently present. They are found in steeper slopes and more eroded soils.

The Micromerio hochreuteneri-Cupressetum atlanticae colonizes more gentle slopes and less eroded soils. It presents a high degree of biodiversity and a high number of Atlas endemic plants. The following are characteristic taxa, not present in the Junipero turbinatae-Cupressetum atlanticae: Capparis spinosa L., Ephedra fragilis Desf., Lavandula pedunculata subsp. atlantica, Olea europaea L. subsp. oleaster (Hoffmanns et Link) Greuter et Burdet, Pistacia atlantica Desf., Rhus tripartita (Ucria) Grande and Micromeria hochreutineri (Briq.) Maire. It makes the association an important element of the ecosystem, which developed independently on the substratum, mostly on the lower parts of the slopes, at altitudes of $1000-2000 \mathrm{~m}$ in the closed valleys of the High Atlas. The open structure of the tree component of these woodland communities allows for the existence of high numbers of species in the open areas (Table 3). The dispersed nature of the tree's occurrence in the woodlands and the presence of the characteristic plants above was 
interpreted as a "pré-steppique" character of these plant communities (Quézel and Barbero 1981). The presence of ruderal plants indicates the long-lasting anthropogenic influence, among them interim cultivation and above of all a pastoralism of the areas covered with associations included within the Ephedro nebrodensis-Juniperion turbinatae Quézel \& Barbero in Asensi et al. (2007) alliance.

\section{Woodland structure}

From the physionomic viewpoint, the woodland formations with $C$. atlantica have received the name of pre-steppe juniper communities (Quézel and Barbero, 1981). These formations, though dominated by trees, nevertheless have a very low percentage coverage, which oscillates between $20 \%$ and $60 \%$ (Appendix 2). The crowns (which fail to form a canopy) modify only to a small degree the light that reaches the inferior woodland layers, and so these strata are composed of heliophilous shrubs and plants woody at the base. Despite the pre-steppe epithet, the herbaceous layer is dominated by small chamaephytes rather than by grasses. This name designates the physionomic aspect of these formations rather than the strict floristic one usually associated with the steppe concept, and so we are speaking of steppe landscape in its wider sense. For these types of formation, perhaps it would be more appropriate to refer to them as open woodland in continental arid environments.

\section{Conservation}

According to IUCN (2006), C. atlantica belongs to the EN $(\mathrm{A} 1 \mathrm{bc}, \mathrm{B} 1+2 \mathrm{~b})$ category. This means that it is considered ENDANGERED, but due to a reduction of the population size, based on direct observation. Such a reduction in the area of the taxon requires that its status be modified (Alac). It occupies an area of less than $100 \mathrm{~km}^{2}$ and is under a continuous process of diminishment (B1b) in conformity with the IUCN (2006). The continuous reduction of the area can be influenced by natural and anthropogenic factors. The natural one is the progressive aridisation of the environment. In this context, gradual climate warming combined with an expected reduction in the precipitation will be a very serious threat for this species. It occurs now where site conditions provide better access to the water on the $\mathrm{N}$ and $\mathrm{W}$-facing slopes and the concave relief forms.

The anthropogenic influence is connected with the direct exploitation of timber and increasing pastoral activity and small-scale agriculture near human settlements. Grazing reduces the woodlands' regenerative capacity, and the exploitation of the wood is linked to traditional uses by the rural society of this valley. A continual dwindling of the area occupied by the tree has been observed in the last few decades, and the present stands are far from the potential area of occupation, and from the 10,000 ha calculated in 1938 by Emberger. Anthropogenic pressure is a fundamental aspect of the landscapes of C. atlantica woodland. In most of the localities regeneration of the species is absent, and its existence is under threat (Alifriqui et al. 1995; Oldfield et al. 1998; Ouahmane et al. 2006). There is an urgent need to take measures to reconcile traditional grazing methods alongside the conservation of the present populations of this endemic cypress (Administration 1992). The cypress woodland from the N'Fiss has been classified as a priority ecological and biological conservation site (F.A.O. 1976; Administration 1992) and an Important Plant Area (Fennane 2004). It should be followed by specific rules for its protection and conservation. At least the plight of $C$. atlantica is not as dramatic as that of $C$. dupreziana, which occurs in Tassili n'Ajjer in the Algerian Central Sahara (Abdoun and Bediaff 2002) and is categorized as critically endangered in the IUCN Red List (2006).

\section{Acknowledgments}

This research was partially funded by the cooperation between the Spanish Research Council (CSIC) and the Polish Academy of Sciences (PAS). We thank $S$ Pyke for improving the English of the text.

\section{References}

Abdoun F., Bediaff M. 2002. Cupressus dupreziana A. Camus: répartition, dépérissement et régénération au Tassili n'Ajjer. Sahara Central. Comptes Rendues Biologies 325: 617-627.

Achhal A. 1986. Étude phytosociologique et dendrométrique des écosystèmes forestiers du bassin versant du N'Fiss (Haut Atlas Central). Thèse Doc. État Univ. Droit Econom. et Sciences d'Aix-Marseille III. Saint Jérôme, p. 204.

Administration 1992. Administration des Eaux et Forêts et de la Conservation des sols. Étude Nationale des Aires protégées du Maroc. Rapports inédits.

Alifriqui M. 1995. La cupressaie endémique de $\mathrm{Cu}$ pressus atlantica Gaussen, un espace présteppique de montagne menacé dans le Haut Atlas occidental marocain. Colloque Bio'mes 1995. Actes des 7èmes rencontres de l'Agence regionale pour l'environnement Provence-Alpes-Cote d'Azur, pp: 163-171.

Alifriqui M., M'Hirit O, Peltier J.P., Tessier L. 1996. Analyse comparée de al croissance radiale du pin d'alep et du cyprès de l'Atlas dans le Haut Atlas 
occidental marocain. Dendrochronologia 14: 7187.

Alifriqui M., M'Hirit O., Michalet R., Peltier J.P. 1995. Variabilité des précipitations dans le Haut Atlas occidentale marocain. Le Climat 13: 11-28.

Asensi A. Diaz-Garretas B., Quézel P. 2007. Plant communities of Juniperus turbinata Guss. subsp. turbinata in the Mediterranean Region. A biogeographical, bioclimatical and syntaxonomical survey. Phytocoenologia 37: 599-623.

Bechir A., El Mousadik A., Cherifi K., Taimi A. 2001. Structure génétique de quatre provenances de $\mathrm{Cu}$ pressus atlantica Gaussen. 2ème Colloque International: Le Genévrier Thurifere et les Forêts d'altitude dans les montagnes du pourtour méditerranéen. Marrakech du 17 au 22 Avril 2001. Livre des résumes.

Bellefontaine R. 1979. Vigueur de croissance du cyprés de l'Átlas (Cupressus atlantica) dans son aire naturelle et dansson aire d'introduction au Maroc. Annales de la Recherche Forestiere au Maroc 19: 235-272.

Benabid A. 2000. Flore et écosystèmes du Maroc. Éditions Ibis Press. Paris, p. 349.

Benabid A., Fennane M. 1994. Connaissances sur la végétation du Maroc: Phytogéographie, phytosociologie et séries de végétation. Lazaroa 14: 21-97.

Boratyński A. 1985. Protected and deserving protection trees and shrubs of the Polish Sudety Mts. with their prealps.1. Juniperus communis L. s.l. Arboretum Kórnickie 30: 111-126.

Braun-Blanquet J. 1979. Fitosociología. E. Blume. Madrid, p. 820.

Brives A. 1909. Voyages au Maroc (1901-1907). Alger, Jourdan. L'Arganier, Appendice: Flore, pp. 605-607.

Charco J. 1999. El bosque Mediterráneo en el norte de África. Agencia Española de Cooperación Internacional. Madrid, p. 671.

Charco J. 2001. Guía de los árboles y arbustos del N de Africa. Agencia Española de Cooperación Internacional. Madrid, p. 370.

Debreczy Z., Racz I. 2011. Conifers around the World. Vols 1-2. DendroPress Ltd. Budapest, p. 1089.

Duponnois R., Ouahmane L., Kane A., Thioulouse J., Hafidi M., Boumezzough A., Prin Y., Baudoin E., Galiana A., Dreyfus B. 2011. Nurse shrubs increased the early growth of Cupressus seedlings by enhancing below ground mutualism and soil microbial activity. Soil Biology and Biochemistry 43: 2160-2168.

Earle J. 2008. Cupressus atlantica. Gymnosperm Database. www.conifers.org.

Ech-Chamikh S. 1983. Productivité du Thuya (Tetraclinis articulata (Vahl) Masters et comportement du Cyprés de l'Atlas (Cupressus atlantica Gauss- en) dans le bassin versant du Nfis (Haut Atlas). Mémoire de 3ème cycle Agronomie. IAVHII, Rabat, p. 127.

El Alaoui El Fels, Roques M.A, Rasplus A., Battesti J-Y, Rouault G. 2001. Les ravageurs des cônes et des graines des Cyprès dans le pourtour méditerranéen: Cas du Cyprès de l'Atlas (Cupressus atlantica Gaussen) 2ème Colloque International: Le Genévrier Thurifere et les Forêts d'altitude dans les montagnes du pourtour méditerranéen. Marrakech du 17 au 22 Avril 2001. Livre des résumes.

El Wahidi F. 2004. Le cyprès de l'Atlas. In: Intini M., Raddi P., Andréoli C. Les espéces de cyprès. CypMed - Interreg III B MedOcc.

Emberger L. 1938. Les arbres du Maroc. Larose Éditeurs, Paris, p. 317.

Emberger L., Maire R. 1941. Catalogue de plantes du Maroc, 4, Suppl. Imprimerie Minerva, Alger.

F.A.O. 1976. Fiches de renseignements sur les essences dont le patrimoine génétique s'appauvrit. Informations sur les ressources génétiques forestières. Doc. fores. occas. 1976/1, no. 5: 22-30.

Farjon A. 2005. A monograph of Cupressaceae and Scyadopitys. Royal Botanic Gardens. Kew, p. 643.

Farjon A. 2010. A handbook of the World's conifers, 1. Brill, Leiden-Boston, p. 526.

Fennane M. 2004. Proposition des Zones Importantes pour les Plantes au Maroc (ZIP Maroc). Rabat. http://cmsdata.iucn.org/downloads/ipas_proposal_morocco.pdf

Fennane M., Ibn Tattou M., Mathez J., Ouyahya A., El Oualidi J. (eds.) 1999. Flore pratique du Maroc, vol. 1. Travaux de l'Institut Scientifique. Série Botanique, 36. Éditions Okad, Rabat.

Fennane M., Ibn Tattou M., Ouyahya A., El Oulaidi J. (eds.) 2007. Flore pratique du Maroc, vol. 2. Travaux de l'Institut Scientifique. Série Botanique, 38. Éditions Okad, Rabat.

Gaussen H. 1950 Espèces nouvelles de Cypres: $\mathrm{Cu}$ pressus atlantica au Maroc, C. ledderi aux Ajjers. Le monde des plantes, Toulouse 45: 55-56.

Griffith, A.J.K. 1998. Taxonomic conservation status of Cupressus atlantica. Dissertation, University of Reading. (Unpublished).

Hollard H., Choubert G., Bronner G., Marchand J., Sougy J. 1985. Carte géologique du Maroc, scale 1:1,000,000. - Serv. Carte géol. Maroc, 260 (2 sheets).

IUCN 2006. The UICN Red list of threatened species. www.iucnredlist.org.

Jahandiez E., Maire R. 1931. Catalogue de plantes du Maroc, 1. Imprimerie Minerva, Alger.

Oldfield S., Lusty Ch., MacKinven M. 1998. The World List of Threatened Trees. World Conservation Press, World Conservation Monitoring Centre, Oxford. 
Ouahmane L., Duponnois R., Hafidi M., Kisa M., Boumezouch A., Thioulouse J., Plenchette C. 2006. Some Mediterranean plant species (Lavandula spp. and Thymus saturejoides) act as potential 'plant nurses' for the early growth of Cupressus atlantica. Plant Ecology 185: 123-134.

Ouahmane L., Hafidi M., Thioulouse J., Ducousso M., Kisa M., Prin Y., Galiana A., Boumezzough A., Duponnois R. 2007. Improvement of Cupressus atlantica Gaussen growth by inoculation with native arbuscular mycorrhizal fungi. Journal of Applied Microbiology 103: 683-690.

Quézel P. 2000. Reflexions sur l'évolution de la flore et la végétation au Maghreb méditerranéen. Ibis Press, Paris, p. 117.

Quézel P., Barbero M. 1981. Contribution a l'étude des formations pre-steppiques à Genévriers au Maroc. Boletim da sociedade Broteriana, ser. 2, 53: 1137-1160.

Quézel P., Barbero M., Benabid A., Rivas-Martínez S. 1994. Le passage de la végétation méditerranéen- ne à la végétation saharienne sur le revers méridional du Haut Atlas oriental (Maroc). Phytocoenologia 22 (4): 537-582.

Quézel P., Médail F. 2003. Écologie et biogeographie des forêts du Bassin Méditerranéen. Elsevier, Paris, $570 \mathrm{p}$.

Rushforth K., Adams R.P., Zhong M., X.-Qiang Ma, Pandey R.N. 2003. Variation among Cupressus species from the eastern hemisphere based on Random Amplified Polymorphic DNAs (RAPDs). Biochemical Systematics and Ecology 31: 17-24.

Silba J. 1981. Revised generic concepts of Cupressus L. (Cupressaceae). Phytologia 49(4): 390-399.

Silba J. 1998. A monograph of the genus Cupressus L. Journal of the International Conifer Preservation Society 5: 1-98.

Watier Ch. 1921. Les Cupressinées dans le Maroc méridional. Bulletin de la Société d'Histoire Naturelle de l'Afrique du Nord 6: 222-240.

(Appendices are at the end of volume.) 

Chorological and conservation status of endemic cypress, Cupressus atlantica Gaussen...

Appendix 1. Locality of populations. groups of trees and single individuals of C. atlantica in N'Fiss Valley (A. Romo. Y. Didukh and A. Boratyński 2005. field observations)

\begin{tabular}{|c|c|c|c|}
\hline Field observations & Lat_N & Long_W & Altitude $[\mathrm{m}]$ \\
\hline \multicolumn{4}{|l|}{ NE of Talat-n-Ya'qoub } \\
\hline Between Outakhri and Ijoukak, N of Foresty, WKL & 30.997 & 8.147 & 1360 \\
\hline Ijoukak, above Forestry, NW, ZB & 30.998 & 8.152 & 1360 \\
\hline Between Outakhri and Ijoukak, $\mathrm{N}$ of Foresty, slopes of the gorge, N, ZB & 30.998 & 8.148 & 1340 \\
\hline Between Outakhri and Ijoukak, $\mathrm{N}$ of Foresty, slope saboe the small gorge, N, ZB & 30.998 & 8.139 & 1430 \\
\hline Between Outakhri and Ijoukak, $\mathrm{N}$ of Foresty, slopes above the road, NW, ZB & 31.004 & 8.151 & 1320 \\
\hline Between Outakhri and Ijoukak, N of Foresty, WKL, W, ZB & 31.008 & 8.134 & 1270 \\
\hline Outakhri, ZB & 31.009 & 8.147 & 1400 \\
\hline Outakhri, ZB & 31.01 & 8.148 & 1350 \\
\hline Outakhri, ZB & 31.011 & 8.15 & 1280 \\
\hline Outakhri, ZB & 31.012 & 8.151 & 1250 \\
\hline Between Alla-n-Mzeghni and Outhakri, WKL, ZB & 31.013 & 8.144 & 1300 \\
\hline Between Alla-n-Mzeghni and Outhakri, WKL, ZB & 31.014 & 8.145 & 1340 \\
\hline Between Alla-n-Mzeghni and Outhakri, WKL, ZB & 31.016 & 8.143 & 1250 \\
\hline Alla-n-Mzeghni, small gorge S of village, N, ZB & 31.018 & 8.139 & 1250 \\
\hline Alla-n-Mzeghni, small gorge S of village, NW and N, ZB & 31.024 & 8.136 & 1200 \\
\hline Targa-n-Ait-Irafene, small gorge above village, N, WKL & 31.034 & 8.148 & 1200 \\
\hline Between Iguer Kouris and Targa-n-Ait Iratene, SW, ZB & 31.035 & 8.139 & 1150 \\
\hline Between Iguer Kouris and Targa-n-Ait Iratene, N, ZB & 31.039 & 8.136 & 1150 \\
\hline Between Iguer Kouris and Targa-n-Ait Iratene, NW, ZB & 31.04 & 8.133 & 1150 \\
\hline Between Iguer Kouris and Targa-n-Ait Iratene, W, WKL & 31.041 & 8.133 & 1120 \\
\hline Targa-n-Ait-Irafene, small gorge $\mathrm{N}$ of village, NE, WKL & 31.042 & 8.143 & 1180 \\
\hline Between Iguer Kouris and Targa-n-Ait Iratene, SW, ZB & 31.042 & 8.133 & 1150 \\
\hline Above Iguer Kouris, W, ZB & 31.049 & 8.133 & 1150 \\
\hline Iguer Kouris, W, WKL & 31.05 & 8.133 & 1160 \\
\hline Between Tigouramine and Tough al Kheyr & 31.06 & 8.138 & 1100 \\
\hline Tigouramine, NE, ZB & 31.069 & 8.136 & 1060 \\
\hline Tough al Kheyr, SW slopes of Jbel Talfanart, ZB & 31.07 & 8.135 & 1060 \\
\hline $\mathrm{N}$ of Iguer Kouris, SW, ZB & 31.56 & 8.134 & 1130 \\
\hline \multicolumn{4}{|l|}{ SW of Talat-n-Ya'qoub } \\
\hline Around Muldirt, NW, WKL & 30.892 & 8.285 & 1610 \\
\hline Tanzzat, $\mathrm{N}$ of village, $\mathrm{N}, \mathrm{WKL}, \mathrm{ZB}$ & 30.902 & 8.293 & 1700 \\
\hline Ifezd ad ene, $\mathrm{S}$ slopes $\mathrm{N}$ of village, WKL, ZB & 30.909 & 8.316 & 1800 \\
\hline Around Muldirt, NE, WKL & 30.909 & 8.288 & 1580 \\
\hline Around Muldirt, NE, WKL & 30.911 & 8.288 & 1530 \\
\hline Idni, $\mathrm{W}$ of village, $\mathrm{N}, \mathrm{ZB}$ & 30.912 & 8.304 & 1650 \\
\hline Idni, near Forestry, NE, ZB & 30.912 & 8.294 & 1600 \\
\hline Idni, near Forestry, NE, ZB & 30.913 & 8.291 & 1550 \\
\hline Idni, near auberge, $\mathrm{ZB}$ & 30.913 & 8.288 & 1610 \\
\hline Idni, $2 \mathrm{~km} \mathrm{~W}$ of village, slopes above the road, E, WKL & 30.914 & 8.306 & 1800 \\
\hline Idni, $\mathrm{W}$ of village, slopes above the road, NW, ZB & 30.914 & 8.303 & 1590 \\
\hline
\end{tabular}




\begin{tabular}{|c|c|c|c|}
\hline Field observations & Lat_N & Long_W & Altitude $[\mathrm{m}]$ \\
\hline Around Muldirt, E, ZB & 30.915 & 8.29 & 1550 \\
\hline Idni, $\mathrm{W}$ of village, slopes above the road, NE, WKL & 30.916 & 8.301 & 1530 \\
\hline Idni, W of village, slopes above the road, NW, WKL & 30.916 & 8.299 & 1560 \\
\hline Idni, $\mathrm{W}$ of village, slopes above the road, $\mathrm{N}, \mathrm{WKL}$ & 30.916 & 8.295 & 1600 \\
\hline Idni, $\mathrm{W}$ of village, slopes above the road, NE, WKL & 30.916 & 8.294 & 1590 \\
\hline Around Muldirt, NE, WKL & 30.916 & 8.285 & 1480 \\
\hline Mouldirt, S of village, N, ZB & 30.916 & 8.278 & 1505 \\
\hline Around Muldirt, SE, WKL & 30.919 & 8.289 & 1500 \\
\hline Around Muldirt, NW, WKL & 30.92 & 8.28 & 1460 \\
\hline Moulddirt, $\mathrm{N}$ of village, NW, WKL & 30.92 & 8.276 & 1520 \\
\hline Isoul, $\mathrm{W}$ of village, $\mathrm{SE}, \mathrm{WKL}, \mathrm{ZB}$ & 30.927 & 8.297 & 1500 \\
\hline Between Isoul and Talatane, SE, WKL, ZB & 30.927 & 8.14 & 1520 \\
\hline Between Isoul and Talatane, SE, WKL, ZB & 30.927 & 8.12 & 1600 \\
\hline Agadir-n-Tagountaft, slopes and gorges around the village, NW, WKL & 30.928 & 8.266 & 1540 \\
\hline Agadir-n-Tagountaft, slopes and gorges around the village, $\mathrm{N}, \mathrm{WKL}$ & 30.93 & 8.272 & 1460 \\
\hline Isoul, NW of village, $\mathrm{E}, \mathrm{WKL}, \mathrm{ZB}$ & 30.932 & 8.23 & 1500 \\
\hline Between Tagmout and Issoul, E, WKL, ZB & 30.933 & 8.29 & 1430 \\
\hline Agadir-n-Tagountaft, slopes and gorges around the village, NW, WKL, ZB & 30.933 & 8.263 & 1490 \\
\hline Tagmout, $\mathrm{N}$ of village, SE, WKL, ZB & 30.934 & 8.29 & 1500 \\
\hline Idni, $\mathrm{W}$ of village, slopes above the road, $\mathrm{NW}, \mathrm{ZB}$ & 30.935 & 8.296 & 1480 \\
\hline Agadir-n-Tagountaft, slopes and gorges around the village, NW, WKL, ZB & 30.935 & 8.257 & 1530 \\
\hline Agadir-n-Tagountaft, slopes and gorges around the village, NW, WKL, ZB & 30.935 & 8.251 & 1590 \\
\hline Between Tagmout and Issoul, E, WKL, ZB & 30.936 & 8.29 & 1510 \\
\hline Agadir-n-Tagountaft, slopes and gorges around the village, S, WKL & 30.936 & 8.264 & 1450 \\
\hline Agadir-n-Tagountaft, slopes and gorges around the village, W, ZB & 30.938 & 8.248 & 1605 \\
\hline Agadir-n-Tagountaft, slopes and gorges around the village, S, WKL & 30.939 & 8.259 & 1600 \\
\hline Ighil, SE of village, N, WKL, ZB & 30.942 & 8.252 & 1720 \\
\hline Between Ighil and Taous, above the main road, N, WKL, ZB & 30.943 & 8.255 & 1600 \\
\hline Tagmout, $\mathrm{N}$ of village, NE, WKL, ZB & 30.944 & 8.278 & 1450 \\
\hline Ighil, SE of village, $\mathrm{N}, \mathrm{WKL}$ & 30.945 & 8.252 & 1650 \\
\hline Between Taous and Tagmout, E, WKL, ZB & 30.946 & 8.28 & 1500 \\
\hline Taous, E slopes $\mathrm{W}$ of village, $\mathrm{ZB}$ & 30.946 & 8.278 & 1430 \\
\hline Between Ighil and Taous, above the main road, N, WKL, ZB & 30.947 & 8.258 & 1500 \\
\hline Ighil, SE of village, N, WKL, ZB & 30.948 & 8.252 & 1550 \\
\hline Ighil, SE of village, N, WKL, ZB & 30.948 & 8.249 & 1520 \\
\hline Between Ighil and Taous, above the main road, N, WKL, ZB & 30.949 & 8.254 & 1400 \\
\hline Between Tasouakt and Ighil, N, WKL, ZB & 30.951 & 8.246 & 1500 \\
\hline Between Tasouakt and Ighil, NW, WKL, ZB & 30.953 & 8.241 & 1560 \\
\hline Ighil, $\mathrm{N}$ of village, $\mathrm{SE}, \mathrm{WKL}, \mathrm{ZB}$ & 30.955 & 8.26 & 1420 \\
\hline Ighil, $\mathrm{N}$ of village, $\mathrm{SE}, \mathrm{ZB}$ & 30.956 & 8.26 & 1510 \\
\hline Ighil, NW of village, E, WKL, ZB & 30.957 & 8.267 & 1520 \\
\hline Ighil, NW of village, E, WKL, ZB & 30.958 & 8.268 & 1620 \\
\hline
\end{tabular}


Chorological and conservation status of endemic cypress, Cupressus atlantica Gaussen...

\begin{tabular}{|c|c|c|c|}
\hline Field observations & Lat_N & Long_W & Altitude $[\mathrm{m}]$ \\
\hline Ighil, NW of village, E, ZB & 30.958 & 8.267 & 1570 \\
\hline Tasouakt, E of village, NW, WKL, ZB & 30.96 & 8.244 & 1450 \\
\hline Ighil, NW of village, E, ZB & 30.961 & 8.262 & 1710 \\
\hline Tasouakt, $\mathrm{W}$ of village, E, WKL, ZB & 30.961 & 8.25 & 1460 \\
\hline Tasouakt, E of village, NW, WKL, ZB & 30.961 & 8.243 & 1550 \\
\hline Between Mzouzit and Tasouakt, NE, WKL, ZB & 30.961 & 8.239 & 1590 \\
\hline Tasouakt, $\mathrm{W}$ of village, $\mathrm{E}, \mathrm{WKL}, \mathrm{ZB}$ & 30.962 & 8.256 & 1520 \\
\hline Between Mzouzit and Tasouakt, N, WKL, ZB & 30.962 & 8.241 & 1450 \\
\hline Mzouzit, $W$ of village, $\mathrm{SE}, \mathrm{ZB}$ & 30.966 & 8.246 & 1330 \\
\hline Mzouzit, $W$ of village, E, ZB & 30.967 & 8.247 & 1450 \\
\hline Mzouzit, E of village, W, WKL, ZB & 30.968 & 8.234 & 1520 \\
\hline Mzouzit, E of village, W, WKL, ZB & 30.968 & 8.232 & 1550 \\
\hline Mzouzit, $\mathrm{W}$ of village, $\mathrm{NE}, \mathrm{ZB}$ & 30.97 & 8.244 & 1280 \\
\hline Mzouzit, E of village, W, WKL, ZB & 30.971 & 8.237 & 1450 \\
\hline Mzouzit, $\mathrm{N}$ of village, $\mathrm{NW}, \mathrm{WKL}, \mathrm{ZB}$ & 30.972 & 8.236 & 1420 \\
\hline Mzouzit, $\mathrm{W}$ of village, $\mathrm{N}, \mathrm{ZB}$ & 30.976 & 8.248 & 1340 \\
\hline Tinmal, N slopes above the road, toward Mzouzit, ZB & 30.976 & 8.221 & 1420 \\
\hline Tinmal, NW slopes above the road, WKL, ZB & 30.978 & 8.223 & 1450 \\
\hline Tinmal, N, ZB & 30.98 & 8.221 & 1400 \\
\hline \multicolumn{4}{|l|}{ TADAFELT } \\
\hline Alous N of Tadafelt, slopes of Adrar Tadafelt, N, WKL & 30.98 & 8.336 & 2050 \\
\hline Alous N of Tadafelt, slopes of Adrar Tadafelt, N, WKL & 30.98 & 8.333 & 2000 \\
\hline Alous N of Tadafelt, slopes of Adrar Tadafelt, N, WKL & 30.982 & 8.333 & 1900 \\
\hline Alous $\mathrm{N}$ of Tadafelt, slopes of Adrar Tadafelt, N, WKL & 30.983 & 8.333 & 1830 \\
\hline Alous N of Tadafelt, slopes of Adrar Tadafelt, N, WKL & 30.984 & 8.33 & 1860 \\
\hline Alous N of Tadafelt, slopes of Adrar Tadafelt, N, WKL & 30.985 & 8.327 & 1790 \\
\hline Alous $\mathrm{N}$ of Tadafelt, slopes of Adrar Tadafelt, N, WKL & 30.985 & 8.326 & 1800 \\
\hline Alous $\mathrm{N}$ of Tadafelt, slopes of Adrar Tadafelt, NE, WKL & 30.986 & 8.334 & 1780 \\
\hline Alous $\mathrm{N}$ of Tadafelt, slopes of Adrar Tadafelt, N, WKL & 30.986 & 8.332 & 1720 \\
\hline Alous $\mathrm{N}$ of Tadafelt, slopes of Adrar Tadafelt, N, WKL & 30.986 & 8.328 & 1710 \\
\hline Alous N of Tadafelt, slopes of Adrar Tadafelt, N, WKL & 30.986 & 8.324 & 1820 \\
\hline Alous $\mathrm{N}$ of Tadafelt, slopes of Adrar Tadafelt, E, ZB & 30.987 & 8.339 & 1930 \\
\hline Alous N of Tadafelt, slopes of Adrar Tadafelt, NE, ZB & 30.987 & 8.338 & 2000 \\
\hline Alous N of Tadafelt, slopes of Adrar Tadafelt, NE, ZB & 30.987 & 8.335 & 1830 \\
\hline Alous $\mathrm{N}$ of Tadafelt, slopes of Adrar Tadafelt, N, WKL & 30.987 & 8.324 & 1710 \\
\hline Alous $\mathrm{N}$ of Tadafelt, $\mathrm{N}$ slopes of Adrar Tadafelt, N, WKL & 30.987 & 8.323 & 1760 \\
\hline S of Iguer, slopes of Adrar Tadafelt, NW, WKL & 30.987 & 8.321 & 1760 \\
\hline S of Iguer, N slopes of Adrar Tadafelt, NW, ZB & 30.987 & 8.32 & 1840 \\
\hline W of Khassaf, N, WKL & 30.988 & 8.348 & 1920 \\
\hline Alous N of Tadafelt, N slopes of Adrar Tadafelt, NE, WKL & 30.988 & 8.333 & 1740 \\
\hline Alous N of Tadafelt, slopes of Adrar Tadafelt, N, WKL & 30.988 & 8.328 & 1650 \\
\hline Alous $\mathrm{N}$ of Tadafelt, $\mathrm{N}$ slopes of Adrar Tadafelt, N, WKL & 30.988 & 8.326 & 1670 \\
\hline
\end{tabular}




\begin{tabular}{|c|c|c|c|}
\hline Field observations & Lat_N & Long_W & Altitude $[\mathrm{m}]$ \\
\hline Alous N of Tadafelt, slopes of Adrar Tadafelt, N, WKL & 30.988 & 8.323 & 1640 \\
\hline S of Iguer, N slopes of Adrar Tadafelt, NW, ZB & 30.988 & 8.32 & 1740 \\
\hline W of Khassaf, NW, ZB & 30.989 & 8.342 & 1750 \\
\hline S of Khassaf, N, WKL & 30.989 & 8.341 & 1950 \\
\hline Alous N of Tadafelt, Adrara Tadafelt, NE, WKL & 30.989 & 8.33 & 1650 \\
\hline Between Khassaf and Iguer, S parts of Jbel Imlit, S ZB & 30.989 & 8.327 & 1660 \\
\hline Alous $\mathrm{N}$ of Tadafelt, $\mathrm{N}$ slopes of Adrar Tadafelt, NE, WKL & 30.99 & 8.335 & 1800 \\
\hline W of Khassaf, N, WKL & 30.991 & 8.347 & 1850 \\
\hline S of Khassaf, NE, WKL & 30.991 & 8.343 & 1920 \\
\hline$S$ of Khassaf, NE, ZB & 30.991 & 8.342 & 1840 \\
\hline S of Khassaf,N, ZB & 30.991 & 8.339 & 1750 \\
\hline W of Khassaf, NW, ZB & 30.992 & 8.347 & 1800 \\
\hline S of Khassaf, NE, ZB & 30.992 & 8.343 & 1740 \\
\hline Between Khassaf and Iguer, S parts of Jbel Imlit, W, ZB & 30.992 & 8.33 & 1670 \\
\hline S of Iguer, slopes of Adrar Tadafelt, SE, WKL & 30.992 & 8.321 & 1630 \\
\hline S of Khassaf, NE, WKL & 30.993 & 8.344 & 1800 \\
\hline$S$ of Khassaf, N, WKL & 30.993 & 8.339 & 1880 \\
\hline E of Khassaf, NE, WKL & 30.993 & 8.336 & 1820 \\
\hline Between Khassaf and Iguer, S parts of Jbel Imlit, W, WKL & 30.993 & 8.33 & 1710 \\
\hline E of Khassaf, W, WKL & 30.995 & 8.338 & 1780 \\
\hline E of Khassaf, NE, ZB & 30.995 & 8.336 & 1790 \\
\hline Alous N of Tadafelt, Adrar Tadafelt, NE, WKL & 30.995 & 8.335 & 1860 \\
\hline Alous N of Tadafelt, slopes of Adrar Tadafelt, N, WKL & 30.995 & 8.332 & 1780 \\
\hline Between Khassaf and Iguer, S parts of Jbel Imlit, NW, WKL & 30.995 & 8.328 & 1950 \\
\hline E of Khassaf, NE, WKL & 30.996 & 8.337 & 1800 \\
\hline E of Khassaf, NE, WKL & 30.996 & 8.336 & 1700 \\
\hline E of Khassaf, NE, WKL & 30.996 & 8.335 & 1680 \\
\hline Between Khassaf and Iguer, S parts of Jbel Imlit, SW, WKL & 30.997 & 8.333 & 1670 \\
\hline Between Khassaf and Iguer, S parts of Jbel Imlit, W, WKL & 30.997 & 8.331 & 1650 \\
\hline Between Khassaf and Iguer, S parts of Jbel Imlit, SW, WKL & 30.997 & 8.33 & 1780 \\
\hline E of Khassaf, N, ZB & 30.998 & 8.337 & 1700 \\
\hline Alous N of Tadafelt, Adrar Tadafelt, N, WKL & 30.999 & 8.329 & 1940 \\
\hline NE of Khassaf, SW, WKL & 31.003 & 8.334 & 1750 \\
\hline
\end{tabular}

Abbrevations: $\mathrm{E}$ - east. eastern; $\mathrm{N}$ - north. northern. NE - north-east. north-eastern. NW - north-west. north-western. S - south. southern. SE - soth-east. south-eastern. SW - south-west. south-western. W - west. western. WKL - concave. WYP - convex. ZB slope 


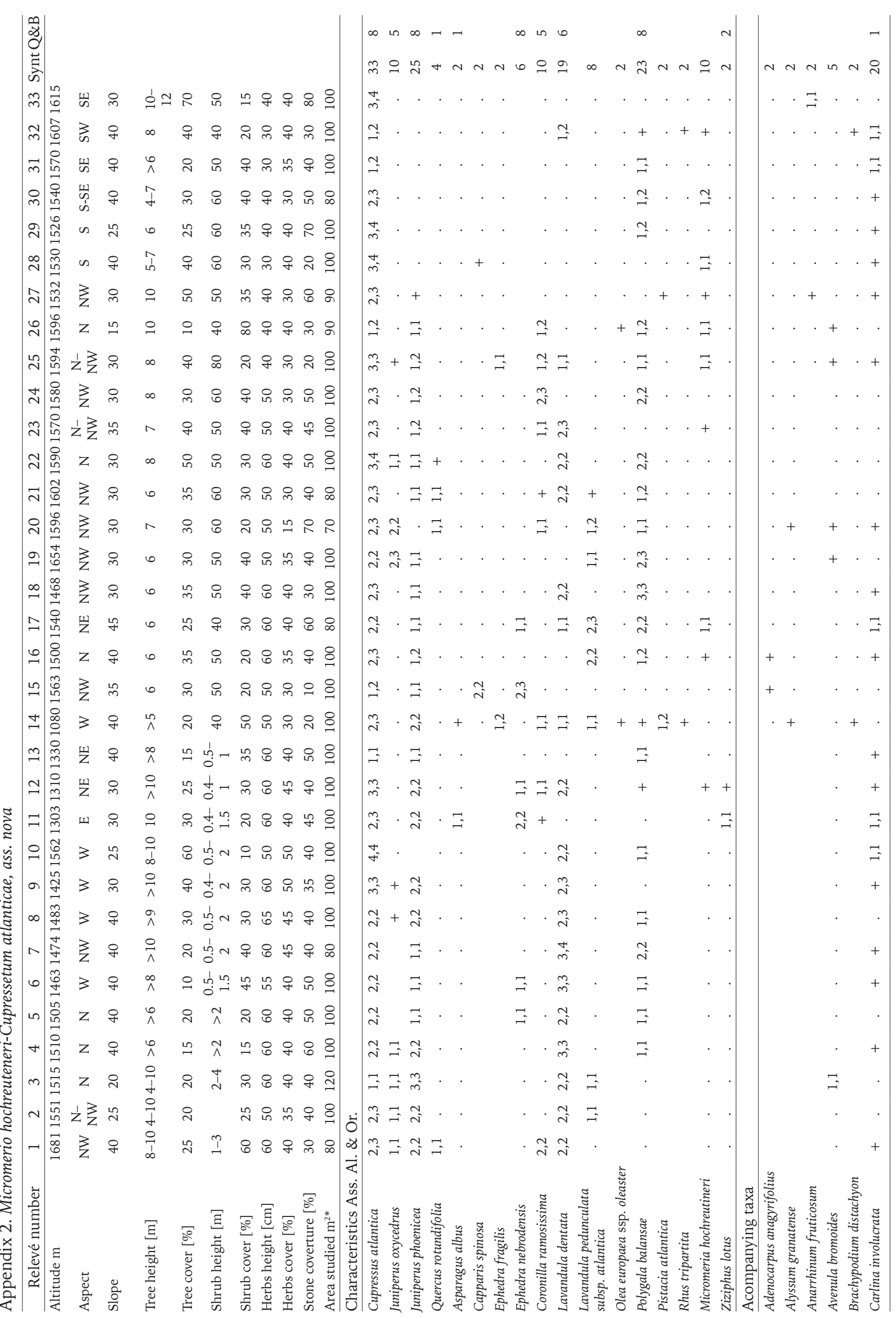




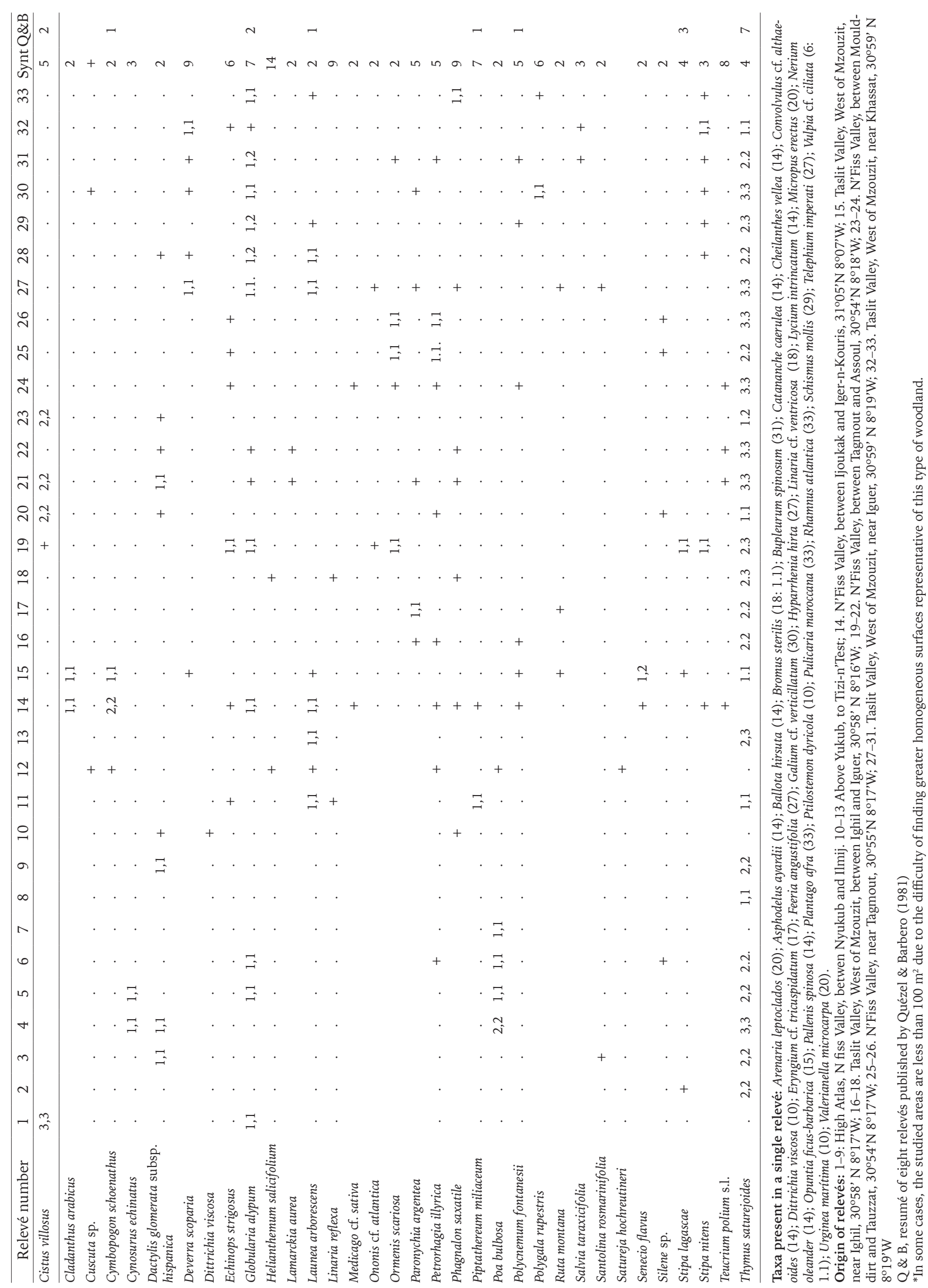

